\title{
The Impact of Culture on English Language Learning
}

\author{
Dr. Mohammed AbdAlla AbdAlgane Mohammed* \\ Assistant Professor of Applied Linguistics, Department of English Language \& Translation, College of Science \\ \& Arts Arrass, Qassim University, KSA
}

*Corresponding Author: Dr. Mohammed AbdAlla AbdAlgane Mohammed, Assistant Professor of Applied Linguistics, Department of English Language \& Translation, College of Science \& Arts Arrass, Qassim University, KSA

\begin{abstract}
This paper aims to highlight the impact of culture on English language learning. Language and culture are considered as inseparable couple and can be simply described as two sides of the same coin. Language is not culture-free. If one is to communicate effectively in a foreign/second language, one cannot ignore the cultural context which gives the words broader meanings. There is no argument about the importance of linguistic competency which is constituted with the knowledge of pronunciation, writing system, vocabulary and grammar syntax for the language production. What is often neglected is cultural competency that is a kind of knowledge of all the other systems of ideas and beliefs shared by members of a community and transmitted through language (Bentahila \& Davies, 1989).

Understanding of culture is very important for understanding any language. Mitchell and Myles (2004) argue that "language and culture are not separate but acquired together, with each providing support for the development of the other" (p. 235). Differences of culture may cause many mistakes. Language not only changes people's values and habits, but also affects people's identity and behaviors. While English language learning involves a number of different skills, including grammar, writing, listening and speaking so this paper will illustrate the impact of English language culture on learning these four language skills.
\end{abstract}

Keywords: English language learning, language and culture relationship, influence of culture, cultural awareness.

\section{INTRODUCTION}

The purpose of this paper is to discuss the intimate and inseparable relation between culture and language and the implementation of instructional approaches and techniques for teaching second language through culture to enhance students' linguistic understanding. Language is not only the product of culture, but also is the symbol of culture (Gleason, 1961). Culture must be incorporated essentially and basically as an essential component of second language learning and teaching. Only after cultural issues become an inherent and natural part of the language curriculum and instruction, can students be successful in their target language learning. Second language teachers, therefore, should pay more attentions to the varieties of cultures, identify key cultural items in every aspect when they design a language curriculum, and apply appropriate teaching strategies to learning activities in order to help students to bridge and overpass the culture gaps. Language is a means of expression. We express our feelings, emotions, thoughts, needs, desires etc. in words, symbols and gesture which is considered as language. Language can be defined as verbal, physical, biologically innate, and a basic form of communication. Culture is the characteristics of a particular group of people, defined by everything from language, religion, cuisine, social habits, music and arts. Thus culture finds its expression in language; so, learning a new language without familiarity with its culture remains incomplete.

Kumagai (1994) cites that as Smith (1987a) claimed in the introduction to Discourse Across Cultures, recognizing such things as the place of silence, appropriate topics of conversation, forms of address, and expressions of speech-acts (e.g. apologies, requests, agreement, disagreement, etc.) are perhaps more important to effective cross-cultural communication than grammar lexis or phonology, since the former are not the same across cultures. In international and cross-cultural communication in which English is used as the main medium, one should neither expect the discourse strategies in English to 
be the same as one's own, nor interpret the language behaviors of others on the basis of one's own cultural presuppositions.

Societies which live in different areas of the world have different cultural upbringings, values, attitudes and backgrounds and use different languages. Language and culture seem on the surface to be two different fields, but they have an entangled relationship and affect each other mutually. Gleason (1961) indicated that languages are not only the products of cultures, but also are the symbols of cultures. The growth of a language frequently affects its associated culture, and cultural patterns of cognition and custom are often explicitly coded in language. Moreover, language is also a social institution, both shaping and being shaped by society (Armour-Thomas \& Gopaul-McNicol, 1998). This means that language is not an independent construct but social practice both creating and being created by the structures and forces of social institutions in which we live and function. Definitely, language cannot exist in a vacuum and there is an inevitable kind of "transfusion" at work between language and culture. Learning a new language will also come with understanding the notions of culture of that target society.

Language is a system of signals, including voice sounds, gestures or written symbols which encodes and decodes information. The aim of language is to communicate meaning and to convey your thoughts to others. When we begin to develop our language abilities, the main purpose is to communicate or interact with others. Alyasery (2018) cites in Halliday (1973, p. 10) suggests that the functions of language can be separated in seven areas, included:

Instrumental function: when language is used to manipulate the environment, to cause certain events to happen.

- Regulatory function: when language controls events. The regulations may encounter the approval or disapproval of the listener.

- Representational function: when language is used to make statements, convey facts and knowledge, explain or report.

- Interactive function: when language serves to ensure social maintenance, this implies knowledge of slang, jargon, jokes, folklore, cultural mores, politeness, and formality expectations in social exchange.

- Personal function: when language expresses feelings, emotions, and personality.

- Heuristic function: when language is used to acquire knowledge and to learn.

- Imaginative function: when language is used to create tales, write a novel, poetry, tongue twisters, etc.

There are four views regarding the issue. The first one states that 'target language culture' should be taught along with English to acculturate language learners into the cultures of English speaking countries (Byram, 1990; Byram \& Flemming, 1998). The second study states that there should not be any teaching of the 'target language culture' together with English in the countries where English is an existing variety( Kachru, B. 1985). Other two views also reject the idea of teaching 'target language culture' along with English. However, while one of the views supports the teaching of 'local culture' in English language teaching (Kramsch \& Sullivan, 1996; McKay, 2003), the other view holds the position that English has become a lingua franca and that's why it should be taught in a culture-free context.( Alptekin, C. 2005

\section{The Role of Culture in English Language Teaching \& Learning}

Saloomeh (2018) cites that the role of context and the circumstances in which language can be used accurately and appropriately. (c.f. Kramsch 1). Culture offers ELT a vast landscape of perspectives that can be employed to enhance the dynamics of a class; even more so among undergraduate students, who have already chosen a certain area of study and may show antipathy or apathy to a teacher's ambitious lesson plan if they do not consider it relevant. So, it is important to know the methods that a teacher might employ in order to avoid "teaching meaningless symbols or symbols to which the student attaches the wrong meaning" (Politzer, 100-101). Dimitrios Thanasoulas pinpoints that up to now there have been two perspectives that have influenced culture teaching and that have served as a model for integrating it to language teaching10: One pertains to the transmission of factual, cultural information, which consists in statistical information, that is, institutional structures 
and other aspects of the target civilization, highbrow information, i.e., immersion in literature and the arts, and lowbrow information, which may focus on the customs, habits, and folklore of everyday life (3).

Just like an efferent reading, all this perspective offers is mere data unable to provoke a deep reflection in the class, and that restricts teachers and students to a mere awareness of the way of life of the country where the information has been taken from. Since there is no other lead around this information that could direct students to contextualize it, their idea of the culture of the country that produces this "amounts to facts," and could remain as sterile as if it came from a printed travel brochure. The other perspective, which draws upon cross-cultural psychology or anthropology, "has been to embed culture within an interpretive framework and establish connections, namely, points of reference or departure, between one's own and the target country" Thanasoulas (2001). According to the author, the limitations of this approach are that it can only give learners cultural knowledge and leaves it to them to integrate it with the assumptions, beliefs and mindsets of their own society. This, however, is where the role of the teacher can make a difference. Like in an aesthetic reading, the teacher needs to guide the students so that they can construct their own interpretation and reflections according to their own experience, by first thinking critically and then comparing and contrasting the two different cultures.

Still, the employment of this model to the ELT is sine qua non. There are many factors to be considered, such as relating new information to existing knowledge, the use of organizing principles to relate conflicting phenomena, and vigorous and critical interaction with knowledge and experience. So, it is fundamental, as Rosenblatt's perspective of aesthetic reading has already established, to keep the communication channels between students and teachers open in order for cultural feedback to run freely from ones to the others. This in turn maintains the active environment of personal and collective creative experimentation. In the end, the role of culture in ELT is crucial, since it will mean the difference between casual speakers who remain outsiders and speakers who understand the meaning behind the words and the world that is constructed by them. As Samovar, Porter, and Jain observe: Culture and communication are inseparable because culture not only dictates who talks to whom, about what, and how the communication proceeds, it also helps to determine how people encode messages, the meanings they have for messages, and the conditions and circumstances under which various messages may or may not be sent, noticed, or interpreted... Culture...is the foundation of communication (24).

Thus, when foreign language learners that have been taught the culture alongside the language encode their messages, they will not do so from a void, but from a deep understanding of what they are saying, its implications and history. They will be able to do much more than communicate simple needs and ideas, and they will be much better equipped to interact within the target language culture and truly give something back and participate in it.

Kumagai (1994) cites that scholars and researchers in the field of applied linguistics as well as language teachers have been addressing the need to incorporate cultural knowledge into second and foreign language teaching (e.g., Lafayette, 1988; Moorjani \& Field, 1988; Patrikis, 1988; Robinson, 1985; etc.). A great deal of research has been done by sociolinguists, communication theorists and anthropologists concerning the strong linkage between the way the language is used and the cultural values which dictate this use (e.g., Hall, 1978; Hymes, 1962; Loveday, 1982; Scollon \& Scollon, 1981; etc.).

Alyasery (2018) cites that culture is the full range of learned human behavior patterns. The term was first used in this way by the pioneer English Anthropologist Edward B. Tylor in his book, Primitive Culture, published in 1871. Tylor said that culture is "that complex whole which includes knowledge, belief, art, law, morals, custom, and any other capabilities and habits acquired by man as a member of society." Of course, it is not limited to men. Women possess and create it as well. Since Tylor's time, the concept of culture has become the dominant focus of anthropology. Culture is a powerful human instrument for survival, but it is a fragile phenomenon. It is constantly changing and easily lost because it exists only in our minds. Our written languages, governments, buildings, and other manmade things are merely the products of culture. They are not culture in themselves.

Therefore, archaeologists cannot dig up culture directly in their excavations. The broken vessels and other artifacts of ancient people that they expose are only material remains that mirror cultural patterns--they are things that were made and used through cultural knowledge and skills. Furthermore, 
Culture is the features of a particular group of people, defined by everything from language, religion, cuisine, social habits, music and arts. Cultures are what make countries unique. Each country has its own different cultural activities and cultural customs. Culture is more than just material goods, that is things the culture uses and produces. Culture is also the beliefs and values of the people in that culture. Culture also includes the way people think about and comprehend the world and their own lives. Culture can also vary within a region, society or sub group. A workplace may have a specific culture that sets it apart from similar workplaces. This province of a country may have a different culture than the rest of the country. For example people in the north of Yemen has a different culture than the people in the south, which is expressed by different ways of talking, different types of music, and different types of dances.in addition to that a family may have a specific set of values, according to the ratio of their belief in religion of that society.

\section{IMPORTANCE OF CULTURE IN LANGUAGE LEARNING}

Alyasery (2018) cites that according to Wei (2005:56), language has a dual character: both as a tool of communication and a carrier of culture. Language without culture is unthinkable, so is human culture without language. A particular language is a mirror of a particular culture. Brown (1994:165) describes the relation between language and culture as follows: 'A language is a part of a culture and a culture is a part of a language; the two are intricately interwoven so that one cannot separate the two without losing the importance of either language or culture'. In a word, culture and language are inseparable (cited in Jiang, 2000: 328). When it comes to the essence of teaching and learning, as Gao (2006) presents it, the interdependence of language learning and cultural learning is so evident that one can conclude that language learning is culture learning and consequently, language teaching is cultural teaching (p.59). Gao further states that foreign language teachers should be aware of the place of cultural studies in foreign language classroom and try to enhance students' cultural awareness and elevate their communication competence. Wang (2008), likewise, asserts that 'foreign language teaching is foreign culture teaching, and foreign language teachers are foreign culture teachers'.

According to Tomalin (2008), the international role of the English language and globalization are the two main reasons to teach culture as a fifth language skill, in addition to listening, speaking, reading and writing. 'What the fifth language skill teaches you is the approach and technique to adapt your use of English to learn about, understand and appreciate the principles, ways of doing things and unique qualities of other cultures. It includes understanding how to use language to accept changes, to be flexible and tolerant of ways of doing things which might be different to yours. It is an attitudinal change that is articulated through the use of language.' Tomalin (2008) further argues that teaching of culture in ELT should include cultural knowledge (knowledge of culture's institution, the big C), cultural values (the 'psyche' of the country, what people think is important), cultural behavior (knowledge of daily routines and behavior, the little c), and cultural skills (the development of intercultural sensitivity and awareness, by means of English language as the tool of interaction).

\subsection{Cultural Influence on Vocabulary}

Language is the transporter of culture and vocabulary is the basic component of language. The cultural difference will inevitably displayed on the vocabulary, and the explanation of vocabulary will also reflect the national or cultural change. If we consider the color as an example in Yemen the white color is used as a represent of virtue, piety and pure and that's why a girl wear white clothes on the day of marriage party as a symbol of goodness, chasteness and faithfulness. On the other hand if we consider this white color in china is completely opposite in their culture and they use it only in funeral when one of the family member is dead. This is also opposing Arabic culture which leads people to wear black clothes in their funeral ceremonies. If an American guy orders hot dog in Arabian restaurant, no one will understand that he is asking a hot sandwich and may be they will laugh at him. Thus, learning a language implies not only the knowledge of its grammar rules and the denotative meanings of words but it implicates much more, such as the culture phenomena, the way of life, customs, food and habits, history and everything that is contained of culture. In a word, culture is a comprehensive combination with abundant implication, and each factor in it may be exhibited on words. Learning vocabulary, while paying attention to cultural factors, is essential and crucial. Otherwise one will be apt to mockery and irony.

\subsection{Cultural Influence on Listening}

Listening to something you are familiar with and is known to you is easier to comprehend and get the 
meaning very quickly, but if you are listening to something which is not familiar to your way of life or some expressions of another culture, a thing you haven't heard about, one will not be able to grasp the meaning. On the contrary, it will be difficult for us to understand, if the materials we are listening to are closely related to the cultural background knowledge we are not familiar with. If somebody says Mohammed is suffering from Alnakheleen day until now. if somebody is not familiar with this province he will not be able to get the idea that Mohammed is suffering from a traffic accident happened in Alnaqkheleen because he does not know that Alnakheleen is a name of a very dangerous mountainy road and many accidents happened there. From the above explanation we can see how important the role that culture plays in our listening ability: Culture is one of its unalienable connections. It can hamper our progress of listening, and it can also help it. So we should notice the existence of culture and try to take advantage of it. Syllabus designers must consider this consideration and make a curriculum which is suitable for cultural background of the students of that place.

\subsection{Cultural Influence on Speaking}

As it is for the skill of listening, the ability of speaking is not a matter only concerned with pronunciation or intonation. People need to read a lot to understand the cultural background knowledge of the target language; only in this way they can communicate successfully with the others and not to be misunderstood or misinterpreted. So in the training of oral English, teachers should emphasize the practical use of the language, and try to use the materials which come from the daily life. This can help people use proper sentences in proper context and proper utterance to a proper situation. Otherwise, even if one may have been well qualified in the linguistic aspect of the language, he may make mistakes or have misunderstanding for the sake of lacking related cultural background knowledge.

Therefore, the experience of a young interpreter is a case in point: There is a young interpreter whose pronunciation is standardized and natural. The first time he was appointed to accompany a foreign guest, he tried to do everything he could to show that he was enthusiastic, kind, considerate, and competent. He tried to be alert as possible by saying "You come this way." "You sit here." "Don't go too fast." "Follow me." "Don't be late." But the next day, he was shocked to know that the foreigner didn't want to go with him, because the foreigner thought that the young interpreter was not polite. In the foreigner's eyes, the interpreter is not helping him, but scolding him as scolding a child. There is no problem in the interpreter's English, but the lack of the cultural background knowledge makes him misunderstood for this job.

Thus we see it clearly that if you don't know the cultural background of some body and you don't know the practical use of the language, what to say in this situation, when and for whom.

\subsection{Cultural Influence on Translating}

It is generally believed that translating is impressively influenced by culture. In translating, we should have enough knowledge about both the target and the source language. The difficulty in translation mostly lies in the understanding of cultural background knowledge. The cultural background knowledge contains many aspects, such as art, history, geography, philosophy, science, etc. As we know each society has its own proverbs and translating many idioms and proverbs used by many speakers in English or in Arabic can be confusing misinterpreted if you don't know the cultural back ground of each society. For example: I was not Pygmalion, I was Frankenstein. There are two points that may puzzle us: one is "Pygmalion", and the other is "Frankenstein". Pygmalion is a symbol of "to enjoy one's own creation", while "Frankenstein" means "to suffer from one's own actions". So the success in translating this sentence does not solely depend on understanding its structure but is determined by the knowledge of the cultural load the two terms carry respectively. Additional examples of culture-related idioms that could be confusing to learners to translate:

- Rob Peter to pay Paul

- Walk down the aisle

- Any/every Tom, Dick, and Harry

- In one's Sunday best

- You're barking up the wrong tree

- Like a square peg in a round hole 
- Burn the midnight oil

\section{Techniques for Developing Cultural Awareness}

There are many opinions about what techniques should be used in the classroom in order to develop cultural awareness in learners. Literature and drama have been found to be very effective for making learners sensitive to alternative cultural perspectives. Role play is a popular method for communicative use of language where students are encouraged to use language imaginatively and creatively. Being based on real-life situations it is always welcome in a role play to use authentic aids from English speaking countries. Drama is similarly useful for directly involving students in crosscultural misunderstanding. A discussion of common proverbs in the target language can help students to understand how the proverbs are different from or similar to proverbs in their mother tongues. Using proverbs as a transferred tool to explore two different cultures can guide students to analyze the similarities and dissimilarities of cultures.

\section{CONCLUSION}

Understanding the relationship between culture and linguistics will help us to develop instructional strategies and pedagogies for teaching second languages. Language is a part of culture and culture is a part of language. The two are strongly dependent on each other and should be taught that way as well. Since motivation is crucial for learning a second language, teachers should aim to make their language instruction as much interesting and contextually relevant as possible. Culturally-based ELT classrooms equip learners with intercultural competencies to successfully communicate in today's globalized world. Foreign culture and one's own culture should be employed together in order for learners to understand a foreign culture.

Learners' interaction with native speakers or text will require them to construct their own meanings rather than having teachers simply transfer information about people and their culture. We put learners' sociocultural background into consideration in choosing materials and educational approaches for particular contexts of teaching since ignoring the students' norms and expectations that is, what students bring to the classroom- is denying the learners' experiences. A lack of consideration of variations in cultures of learning can lead to frustration and subsequent failure in language classrooms. Mastering in a language requires learners' mastery of the cultural contexts in which important social acts occur because it conveys warm feelings and solidarity among speakers and is categorized in the 'social' use of language. Language learners need to comprehend what native speakers mean when they use the language, even if they do not choose to replicate native speakers' behavior. After all, the more cultural concepts we learn, the more language abilities we gain; the more language we gain, the more effectiveness we have.

\section{REFERENCES}

[1] Alptekin, C. 2005. 'Dual language instruction: Multiculturalism through a lingua franca'. TESOL Symposium on Dual Language Education: Teaching and Learning Two Languages in the EFL Setting. September 23, 2005. Bogaziçi University, Istanbul, Turkey.

[2] Alyasery Abdulqawi H. (2018). The impact of culture on English language learning in the Arab world. English Department, Aligarah Muslim University, India.

[3] Armour-Thomas, E. \& Gopaul-McNicol, S. (1998). Assessing Intelligence: A Bio-Cultural Model. Sage Publications, INC.

[4] Bentahila, A. \& Davies, E. (1989). Culture and language use: A problem for foreign

[5] Brown, H. D. (1994). Principles of language learning and teaching. Englewood Cliffs, New Jersey: Prentice Hall Regents. 27, 99-112.

[6] Byram, M. \& Flemming, M. (Eds.) 1998. Language Learning from an Intercultural Perspective. Cambridge: Cambridge University Press.

[7] Byram, M. Morgan, C. (1994). Teaching and Learning Language and Culture. England: Multilingual Matters.

[8] Byram,M. Morgan, C., \& Colleagues. (1994). Teaching and Learning Language and Culture: Great Britain: WBC 254

[9] Express, an International Journal of Multi Disciplinary Research ISSN: 2348 - 2052, Vol. 1, Issue 4, April 2014 Available at: www.express-journal.com

[10] Fleet, M. (2006). The Role of Culture in Second or Foreign Language Teaching: Moving Beyond the Classroom Experience. ERIC Journal Number. ED491716 Available at: http://eric.ed.gov/ERICDocs/data/ ericdocs2sql/content_storage_01/000019b/80/1b/d0/c9.pdf 
[11] G. Brown. (1990). Cultural Values: The Interpretation of Discourse. ELT, (1): 11-17.

[12] Gao, F. (2006). Language is Culture - On Intercultural Communication. Journal of Language and Linguistics, 5(1), 58-67

[13] Gleason, H. S. Jr., (1961). An Introduction to Descriptive Linguistics. New Delhi: Oxford and IBH Publishing Company.

[14] Halliday, M. (1973). Exploration in the Function of Language. London: Edward Amold.

[15] http://express-journal.com/pdf/april14issue4/theroleofcultureinelt_rahimuddin.pdf.

[16] http://www.teachingenglish.org.uk/think/articles/culture-fifth-language-skill

[17] Jiang, W. T. (2000). The Relation Between Language and Culture. EFT Journal, 54.

[18] Kachru, B. B. 1985. Standards, codification and sociolinguistic realism: The English language.

[19] Kramsch, C. \& Sullivan P. 1996. 'Appropriate pedagogy'. ELT Journal 50/3: 199-212

[20] Kramsch, C. (1993). Context and culture in language teaching. Oxford: Oxford University Press

[21] Kramsch,B. (1988). The Cultural Discourse of Foreign Language Textbooks. In: A. namregniS, ed. Towards a New Integration of Language and Culture. Middlebury, VT: Northeast Conference: 63-68.

[22] Kumagai, Yuri, (1994). "The Effects of Culture on Language Learning and Ways of Communication: The Japanese Case". Master's Capstone Projects. 80.

[23] Kuo, M.-M., \& Lai, C.-C. (2006). Linguistics across Cultures: The Impact of Culture on Second Language Learning. Journal of Foreign Language Instruction, 1-10. Retrieved from https://eric.ed.gov/?id= ED496079 language teaching. International Review of Applied Linguistic in Language Teaching,

[24] McKay, S. (2002). Teaching English as an International Language: Rethinking Goals and Approaches. Oxford: Oxford University Press

[25] McKay, S. 2003. 'Teaching English as an international language: The Chilean context'. ELT Journal 57/2: 139-48

[26] Retrieved from https://scholarworks.umass.edu/cie_capstones/80

[27] Saloomeh, Jahanforouz. (2018). The Role of Literature and Culture in English Language Teaching, Payame Noor University.

[28] Thanasoulas, Dimitrios. 2001 "The Importance Of Teaching Culture In The Foreign Language Classroom" in Radical Pedagogy. 31 October 2008. <http://radicalpedagogy.icaap.org/>

[29] Tomalin, B., \& Stempleski, S. (1993). Cultural Aware- ness, Oxford: Oxford University Press.

[30] TomalinB. (2008). Culture - the fifth language skill. Available at

[31] Wang, X.-y. (2008). Reflection on the notion of culture teaching. US-China Foreign Language, 6(1), 49-53

[32] Wei, Y. (2005). Integrating Chinese Culture with TEFL in Chinese Classroom. Sino-US English Teaching, 2(7), $55-58$

\section{Author's Biography}

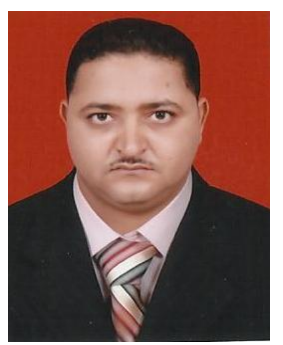

Dr. Mohammed Abdalla AbdAlgane Mohammed, is an assistant professor of Applied Linguistics at Qassim University. Awarded Ph.D. from University of Gezira, Sudan (2011). The author has several publications including:

1. Mohammed. A. AbdAlgane. (December, 2019). An Approach to English Phonology, International Journal of Linguistics, Literature and Translation, ISSN: 2617-0299, Vol. 2, Issue 7, pp: (108 - 120), Al-Kindi Center for Research and Development, Jordan.

2. Mohammed. A. AbdAlgane. (January, 2020). Utilizing Technology in ELT Classrooms. Open Access Library Journal, ISSN: 2333-9721, Vol. 7, e6016, USA.

3. Mohammed. A. AbdAlgane. (January, 2020). English Language \& Globalization. International Journal of Novel Research in Education and Learning, ISSN: 2394-9686, Vol. 7, issue 1, pp: (511), Lucknow: Novelty Journals, India.

Citation: Dr. Mohammed AbdAlla AbdAlgane Mohammed. The Impact of Culture on English Language Learning. "International Journal on Studies in English Language and Literature (IJSELL), vol 8, no. 1, 2020, pp. 21-27. doi: http://dx.doi.org/10.20431/2347-3134.0801003.

Copyright: (C) 2020 Authors. This is an open-access article distributed under the terms of the Creative Commons Attribution License, which permits unrestricted use, distribution, and reproduction in any medium, provided the original author and source are credited. 